\title{
Chapter 1 Introduction
}

\begin{abstract}
The regeneration of brownfields in European metropolitan areas represents an important potential to mitigate urban sprawl by increasing density within the existing built fabric and to revitalize portions of cities at the neighbourhood scale. Although research and projects on urban brownfields are active, several issues still need to be overcome, especially regarding the sustainability transition challenge. Based on this observation, we introduce the present book, which proposes an integrated and theoretically grounded approach to highlight how urban brownfield regeneration projects — and the neighbourhood scale that they entail—can effectively contribute to the urban sustainability transitions of metropolitan areas. It is structured in two parts that are both distinct and complementary: the first part aims to clarify the framework of the investigations with definition and analysis and the second part presents a deep analysis of processes, project dynamics, and sustainability assessment approaches of urban brownfield regeneration.
\end{abstract}

Keywords European metropolitan areas - Urban brownfield regeneration • Neighbourhood scale $\cdot$ Sustainability transitions • Urban sprawl • Urban design • Architectural design

Observation of post-industrial European metropolitan areas reveals a singular paradox spanning decades. While planning politics seek to limit urban sprawl in order to slow the occupation of space, pressure on the landscape and its impacts on the environment, a considerable stock of land in the heart of urban territories still remains neglected or underutilized (Rey 2014).

Emblematic of a post-industrial era, their widespread appearance can be explained by the significant reduction or technological change in certain activities within the European territories. The disappearance of obsolete activities, the relocation of certain functions, the automation of production, or other changes in needs have locally imbalanced the relationships between functional needs and their spatial extent. Going beyond the sole question of industrial sectors, these urban brownfields may also have previously hosted activities such as railway, military, port, logistics, infrastructural, commercial, or energy concerns. Yet, these urban brownfields represent an important potential: their regeneration allows the mitigation of urban sprawl by increasing 
density within the existing built fabric - in particular when located near public transport-and to revitalize portions of metropolitan areas at the neighbourhood scale (Rey 2012).

Among the pioneering examples of urban regeneration, we can cite in particular the Internationale Bauausstellung Emscher Park (IBA Emscher Park), which constituted an ambitious programme for structural changes in the so-called German Ruhr region from 1989 to 1993 (Nordrhein-Westfalen Minister für Stadtentwicklung 1988). In a context of strong industrial decline, this approach consisted of a kind of laboratory for the implementation of new concepts in brownfield transformation processes, integrating diverse sociocultural and ecologic dimensions. In the spirit of these first experiences, a growing number of urban brownfield regeneration projects have emerged in Europe over the past twenty years. The projects already carried out and the many sites still in the study phase are not limited to regions with a strong industrial past, but today concern a particularly large number of European metropolitan areas.

Arousing the interest of the various players in regional planning, these achievements have helped to overcome certain negative perceptions traditionally associated with declining sites and to recognize their development potential. However, they did not reduce the importance of the phenomenon, which remains more relevant than ever at a time of climate crisis. Many abandoned or underused sites are still waiting for new programmes, whether by hosting emblematic public institutions or, more broadly, by integrating a functional mix allowing links with the surrounding urban fabric to be re-established.

Although research and projects on urban brownfields are active, several issues still need to be overcome, especially regarding the sustainability transition challenge. With this in mind, the question is not limited solely to considerations of location and building densification. If density is an inescapable challenge, it ought to be considered as a necessary but not sufficient condition. Our observation of multiple regeneration projects highlighted that they do not automatically contribute to the sustainability of urban areas. To achieve sustainability, the integration of a proactive and continuous search for global quality into the dynamics of the project is essential (Rey et al. 2015). This involves taking into account multiple environmental, sociocultural, and economic dimensions from the first steps of the project, then careful monitoring of the sustainability objectives during the various stages of the design process until the commissioning of the new neighbourhoods.

It is in this spirit that this book proposes an integrated and theoretically grounded approach to highlight how urban brownfield regeneration projects - and the neighbourhood scale that they entail — can effectively contribute to the urban sustainability transitions of metropolitan areas. The challenge is undeniably significant and its accomplishment requires planning, conscience, and a mastery of complex processes. In terms of practice and usage, such an evolution must be accompanied by a true reappraisal of urban lifestyles. This requires the emergence of a habitat offering an increased quality of life to an increased number of inhabitants, while simultaneously promoting a sparse use of resources, a move towards carbon neutrality, and a minimization of environmental impacts. The health crisis induced by the COVID-19 
pandemic has further heightened awareness of the necessary conditions for ensuring well-being within dwellings and to meet the need for services and amenities in a perimeter easily accessible on foot or by bicycle.

This search for quality and proximity, understood broadly, finds at the neighbourhood level a framework of actions and experiments that are particularly adapted in operational terms. This makes it possible to grasp the urban reality in a dimension vast enough to touch on sustainability criteria that go beyond the size of a single building, but circumscribed enough to be able to visualize concrete interventions. The neighbourhoods thus lend themselves well to a tangible realization of sustainability transitions, for example, by the increase in sustainable mobility, development of public spaces, development of local services, energy renovation of existing buildings, construction of new low-carbon buildings, promotion of the circular economy, and the realization of true sociocultural and intergenerational diversity.

Such projects should be understood as a dynamic process which involves many actors and underpins a common learning of how sustainability can be transposed in each operation. This subject is important because urban brownfield regeneration projects are not inherently sustainable. That is explained by the complexity of the nature of urban brownfields and their scale, the project process, and the holistic concept of sustainability itself. To overcome these complexities, a good understanding of the nature of urban brownfields and regeneration projects' process is required. Moreover, evaluation and monitoring are necessary approaches to ensure the integration of sustainability objectives into these operations.

Based on these findings and multiple works carried out within the Laboratory of Architecture and Sustainable Technologies (LAST) of the Ecole polytechnique fédérale de Lausanne (EPFL), the present book is structured in two parts that are both distinct and complementary. The first part aims to clarify the framework of the investigations presented by an effort to define the polysemic concept of brownfield and by an analysis of the different risks of their regeneration in regard to their potential contribution to the sustainability transition of European metropolitan areas. Highlighting the heterogeneity of situations, our presentation of a number of examples allows us to illustrate the phenomenon of urban brownfields and certain characteristics of their regeneration.

The second part of the book next presents a deep analysis of processes, project dynamics, and sustainability assessment approaches of urban brownfield regeneration. It highlights that the optimizations of the project are part of an iterative search for improvement and that all key players must be involved in this complex process. For this to happen, it is necessary to have an increased knowledge of the initial situation, and to define common objectives with the various actors, then assess whether they have been reached in order to draw concrete conclusions in the form of changes to the project and targeted adaptations of operational actions. It is for this reason that the book also provides an operational monitoring tool specifically focusing on issues raised by urban brownfield regeneration projects, whose method and principles can be concretely transferred as tools for supporting decision-making in professional practice (Laprise et al. 2018). The application of this tool was tested in real case studies in three selected neighbourhoods in Liège (Belgium), Yverdon-les-Bains 
(Switzerland) and Besançon (France), and the outcomes of the latter case study are also presented and discussed.

Thus, these two complementary parts constitute a theoretical and practical reference book that provides detailed information on urban brownfield regeneration projects as contributions - at their own scale - to the evolution of European metropolitan areas. Faced with the current ecological and climate crises, urban areas represent both a huge challenge and a formidable potential. Among the multitude of actions to be undertaken and taking into account the long timeframe which characterizes urban projects, sustainable brownfield regeneration remains an unmissable issue, and a relevant operational strategy. In other words, at the beginning of the twenty-first century, a regeneration project constitutes a neighbourhood in transition that turns urban brownfield potential into opportunities for sustainability. In this light, this book attempts to highlight that rethinking urban territories through the prism of the neighbourhood scale gives the advantage of sufficient circumscription to be tangible, yet large enough to have an impact.

\section{References}

Laprise M, Lufkin S, Rey E (2018) An operational monitoring tool facilitating the transformation of urban brownfields into sustainable neighborhoods. Build Environ 221-233. https://doi.org/10. 1016/j.buildenv.2018.06.005

Nordrhein-Westfalen Minister für Stadtentwicklung W und V (1988) Internationale Bauausstellung Emscher-Park Werkstatt für die Zukunft alter Industriegebiete: Memorandum zu Inhalt und Organisation. Minister für Stadtentwicklung, Wohnen und Verkehr des Landes NordrheinWestfalen, Düsseldorf

Rey E (2014) From Spatial Development to Detail. Quart Publishers, Lucerne, Collection Notatio Rey E (2012) Régénération des friches urbaines et développement durable : vers une évaluation intégrée à la dynamique du projet. Presses Universitaires de Louvain, Louvain-La-Neuve

Rey E (ed) (2015) Urban recovery. Presses Polytechniques et Universitaires Romandes, Lausanne

Open Access This chapter is licensed under the terms of the Creative Commons Attribution 4.0 International License (http://creativecommons.org/licenses/by/4.0/), which permits use, sharing, adaptation, distribution and reproduction in any medium or format, as long as you give appropriate credit to the original author(s) and the source, provide a link to the Creative Commons license and indicate if changes were made.

The images or other third party material in this chapter are included in the chapter's Creative Commons license, unless indicated otherwise in a credit line to the material. If material is not included in the chapter's Creative Commons license and your intended use is not permitted by statutory regulation or exceeds the permitted use, you will need to obtain permission directly from the copyright holder. 